\title{
Antinociceptive effect of methanol extract of Celosia cristata Linn. in mice
}

\author{
Shanta Islam, Md Shafiullah Shajib ${ }^{*}$ and Tajnin Ahmed
}

\begin{abstract}
Background: Celosia cristata Linn. (Amaranthaceae) is used in traditional medicine for the treatment of headache, sores, ulcers, eye inflammations, skin eruption, painful menstruation and carpal tunnel syndrome. This study was performed to evaluate the antinociceptive activity of methanol extract of the whole plant of C. cristata (MECC).

Methods: The evaluation of the antinociceptive effect of MECC was performed using thermal (hot plate, tail immersion test) and chemical (acetic acid, formalin, and glutamate-induced nociception test) pain models in mice at four different doses (50, 100, 200, 400 mg/kg; p.o.). Involvement of opioid receptors mediated central antinociceptive mechanism of MECC was evaluated using naloxone. Furthermore, the association of ATP-sensitive $\mathrm{K}^{+}$channel and cGMP pathway were evaluated using glibenclamide and methylene blue respectively.
\end{abstract}

Results: Oral treatment of MECC produced significant, strong and dose-dependent central and peripheral antinociceptive effect in experimental pain models. MECC significantly increased the latency time of thermal threshold in both hot plate and tail immersion test. The inhibition of writhing syndrome by the extract in the acetic acid-induced writhing test was remarkable. MECC significantly reduced the formalin-induced neurogenic and inflammatory pain. In addition, the inhibition of glutamate-induced paw licking and edema by MECC was significant. The antinociceptive effect was significantly reversed by naloxone and glibenclamide, suggesting the association of opioid and ATP-sensitive $\mathrm{K}^{+}$channel system respectively. In addition, MECC also demonstrated the involvement of cGMP pathway in the antinociceptive action.

Conclusion: The study suggests that C. cristata possess significant antinociceptive effect which is associated with both central and peripheral mechanisms and provides a rationale for its extensive use at different painful conditions in traditional medicine.

Keywords: Celosia cristata Linn, Amaranthaceae, Medicinal plant, Antinociceptive, Opioid system

\section{Background}

Celosia cristata Linn. (commonly known as Cockscomb) is an annual herb from Amaranthaceae family. It is locally called 'Moragphul' and grown in the garden as an ornamental plant in Bangladesh. The plant is applied for the treatment of headache, sores, ulcers, eye inflammations, skin eruption, painful menstruation and carpal tunnel syndrome in ethnomedicine [1-4]. Flower of the plant is used in the treatment of abdominal pain, epistaxis, hemoptysis, hematuria, hematemesis and painful bones [5-7]. Leaves are used in cuts, wounds and body

\footnotetext{
* Correspondence: shafiullahshajib@gmail.com

Department of Pharmacy, Stamford University Bangladesh, 51 Siddeswari Road, 1217 Dhaka, Bangladesh
}

(c) The Author(s). 2016 Open Access This article is distributed under the terms of the Creative Commons Attribution 4.0 International License (http://creativecommons.org/licenses/by/4.0/), which permits unrestricted use, distribution, and reproduction in any medium, provided you give appropriate credit to the original author(s) and the source, provide a link to the Creative Commons license, and indicate if changes were made. The Creative Commons Public Domain Dedication waiver (http://creativecommons.org/publicdomain/zero/1.0/) applies to the data made available in this article, unless otherwise stated. mouth sores, inflammation of the ciliary body, cornea and iris and piles $[6,10]$. Branches and roots are used in leucorrhea [11].

The plant contains asparagine, asparagine-linked glycon, protein, glycoproteins [2]. Hyaluronic acid (HA) has been found in the plant [12]. The aerial parts of the plant contain cristatein and tlatlancuayin [13]. Seeds of the plant have been reported to contain 5-hydroxy-7methoxyflavone, 5-methoxy-6,7-methylenedioxyflavone, 5-hydroxy-6,7-dimethoxyflavone 5,7-dimethoxyflavone, cochliophilin A, kaempferol, stigmasterol, $\beta$-sitosterol, 4hydroxyphenethyl alcohol, 2-hydroxyoctadecanoic acid, saponins named celosin A, B, C and D, cristatain and semenoside A [13-16]. Antiviral glycoproteins named 
CCP-25 and CCP-27 have been found in leaves [17]. Betanin has been found in the callus line of the plant [18]. In vivo and in-vitro studies reported anti-inflammatory activity of betanin [19]. The isolated compound, HA, has been reported to effective against inflammations like dermal, corneal wound and osteoarthritis [20, 21]. Tlatlancuayin has been reported to possess cell renewal and antioxidant properties [22]. Cristatain and semenoside A, isolated from seeds, have been reported to exhibit hepatoprotective activity in mice $[15,16]$. Pharmacological investigations reported the antioxidant, anti-aging, adipogenesis reduction and acetylcholinesterase, butyrylcholinesterase, tyrosinase enzyme inhibition activity of the plant [23-25]. In vivo studies of the flower of the plant in mice and rabbits showed significant hemostatic action. Leaves of the plant have been reported to possess anthelmintic activity [26]. In vivo study of the leaves demonstrated the suppression of development of benign prostate hyperplasia $(\mathrm{BPH})$, a disease associated with oxidative stress and inflammatory process [27]. In vitro study of the crude extract of the plant exhibited anti-inflammatory activity by suppression of histamine release and arachidonic acid synthesis [28].

The application of $C$. cristata in different painful states in traditional medicine, anti-inflammatory action of its crude extract as well as isolated compounds and lack of scientific report regarding its antinociceptive action prompted us to conduct the present study to evaluate the effect of methanol extract of C. cristata (MECC) whole plant using different thermal and chemical nociceptive models in mice.

\section{Methods}

\section{Plant material and extraction}

Celosia cristata were collected from the Gowsul Azam Nursery, Kamalapur, Dhaka, Bangladesh on November 27, 2014. The collected plants were identified by Bushra Khan, Principal Scientific Officer, Bangladesh National Herbarium, Mirpur, Dhaka, Bangladesh and a voucher specimen (DACB: 41890) has been deposited for further reference. The plant material was shade dried and grounded. Then $205 \mathrm{~g}$ of powdered material were macerated by $1000 \mathrm{~mL}$ of methanol. The solution was occasionally stirred at $25 \pm 2{ }^{\circ} \mathrm{C}$ for 7 days and then filtered using sterilized cotton and Buchner funnel. The filtrate was concentrated to evaporate solvent using rotary evaporator at $40{ }^{\circ} \mathrm{C}$ and 50 r.p.m. Finally, $14.26 \mathrm{~g}$ (yield $6.96 \%$ ) of dried extract was obtained and this crude extract was used for phytochemical screening, toxicity, and antinociceptive activity studies.

\section{Chemicals and drugs}

The chemicals and drugs used in the present study are methanol, toluene, ethyl acetate, dichloromethane, vanillin, sulphuric acid, Folin-Ciocalteu's reagent, aluminum chloride, $\mathrm{Na}-\mathrm{K}$ tartrate, formalin, acetic acid, L-glutamic acid, (Merck Co., Darmstadt, Germany), DPPH (2,2-Diphenyl-1-picrylhydrazyl), ascorbic acid, quercetin, stigmasterol, methylene blue, pentobarbital sodium (Sigma Co., St. Louis, MO, USA), digoxin (Aristopharma Ltd., Shampur, Dhaka, Bangladesh), atropine, morphine sulfate (Gonoshasthaya Pharmaceuticals Ltd., Savar, Dhaka, Bangladesh), diclofenac sodium (Novartis Bangladesh Ltd., Gazipur, Dhaka, Bangladesh), glibenclamide (Square Pharmaceuticals Ltd., Gazipur, Dhaka, Bangladesh), naloxone hydrochloride (Samarth Life Sciences Pvt. Ltd., Nalagarh, Himachal Pradesh, India).

\section{Animals}

Swiss albino male mice with 20-25 g body weight (b.w.) were collected from Animal Resources Branch of the International Center for Diarrhoeal Disease Research, Bangladesh (icddr,b) The animals were acclimatized for 14 days in laboratory condition before experiments. The animals were housed in $120 \times 30 \times 30 \mathrm{~cm}$ cages at standard laboratory environment (room temperature $25 \pm 2{ }^{\circ} \mathrm{C}$; relative humidity 55-60\%; $12 \mathrm{~h}$ light-dark cycle) and were provided with standard diet (icddr,b formulated) and tap water ad libitum. Flake wood shavings were used for bedding. Health status of animals was monitored every day. The animals were randomly selected and divided into control, positive control and experimental group $(n=5)$ for each experiment. The animals were abstained from food overnight only before experiments. All the experiments were carried out in accordance with The Swiss Academy of Medical Sciences and the Swiss Academy of Sciences formulated Ethical Principles and Guidelines for Scientific Experiments on Animals (1995) and performed under the approval of Ethics Committee of Stamford University Bangladesh (SUB/IAEC/14.07). The acute oral toxicity test was carried out following the guideline (420 - fixed dose procedure) of Organization for Economic Cooperation and Development (OECD). The animals were euthanized using pentobarbital in accordance with AVMA guidelines for the Euthanasia of Animals: 2013 Edition and made all efforts to alleviate animal suffering.

\section{Drugs and treatments}

The control group orally received vehicle ( $0.9 \%$ sodium chloride) at the dose of $10 \mathrm{~mL} / \mathrm{kg}$ (b.w.) $30 \mathrm{~min}$ before the experiments. The positive control group intraperitoneally (i.p.) received standard drug morphine in hot plate, tail immersion and formalin-induced licking test at the dose of $5 \mathrm{mg} / \mathrm{kg}$ and diclofenac sodium in acetic acid-induced writhing and glutamate-induced paw licking test at the dose $10 \mathrm{mg} / \mathrm{kg} 15 \mathrm{~min}$ before the experiments. MECC was administered orally at the doses of 50, 100, 200, $400 \mathrm{mg} / \mathrm{kg}$ (b.w.) $30 \mathrm{~min}$ before the 
experiments. The doses of MECC were selected from trial and previously reported effective doses of $C$. cristata [29]. To evaluate the involvement of opioidmediated antinociceptive activity, naloxone was administered (i.p.) at the dose of $2 \mathrm{mg} / \mathrm{kg} 15 \mathrm{~min}$ before morphine sulfate or MECC administration in the hot plate and tail immersion test. Methylene blue $(20 \mathrm{mg} /$ $\mathrm{kg})$ and glibenclamide $(10 \mathrm{mg} / \mathrm{kg})$ were intraperitoneally employed 15 min before vehicle or $\operatorname{MECC}(50,100,200$ and $400 \mathrm{mg} / \mathrm{kg}$ ) administration to evaluate the involvement of cyclic guanosine monophosphate (cGMP) and ATP-sensitive $\mathrm{K}^{+}$channel pathway respectively. All the doses of drugs and MECC were prepared using the vehicle.

\section{Phytochemical analysis}

\section{Phytochemical screening}

MECC was qualitatively tested for the detection of proteins, carbohydrates, steroids, saponins, alkaloids, flavonoids, tannins, glycosides and resins following standard procedures [30]. The phytoconstituents of MECC was further authenticated by thin layer chromatography (TLC). Aliquots of $(10 \% \mathrm{w} / \mathrm{v}$ dissolved in methanol) MECC extract was spotted on pre-coated silica gel $60 \mathrm{~F}_{254}$ plates (Merck Co., Darmstadt, Germany). The phytochemical profile was obtained using different solvent systems as flavonoids, phenolics and steroids (toluene: ethyl acetate: acetic acid (9:1:1); glycosides (ethyl acetate: methanol (10:1); alkaloid (dichloromethane: methanol (8:1). A collection of standard phytochemicals such as quercetin, gallic acid, stigmasterol, digoxin, and atropine were co-chromatographed for flavonoids, phenolics, steroids, glycosides, alkaloids respectively. The developed chromatographed plates were visualized under visible $(254 \mathrm{~nm})$, UV light (356 nm) or using suitable spraying reagents (such as steroid by $1 \% \mathrm{w} / \mathrm{v}$ vanillin-sulphuric acid solution, glycosides by sulphuric acid, alkaloid by Dragendorff's reagent) [31]. Then retention factor $\left(R_{f}\right)$ for each spot was determined as $R_{f}=$ distance travelled by the solute/distance travelled by the solvent). Each experiment was carried out twice and the mean $R_{f}$ values were compared with the standard markers.

\section{Determination of phenolic content}

The total phenolic content (TPC) was determined using Folin-Ciocalteu's reagent [32]. $1 \mathrm{~mL}$ of MECC $(200 \mu \mathrm{g} /$ $\mathrm{mL}$ ) was mixed with $0.5 \mathrm{~mL}$ of Folin-Ciocalteu's reagent. 5 min later $4 \mathrm{~mL}$ of sodium carbonate $(7.5 \% \mathrm{w} / \mathrm{v}$ in distilled water) solution was added to the mixture. The solution was incubated at $20{ }^{\circ} \mathrm{C}$ for $60 \mathrm{~min}$. The absorbance of the solution was read at $765 \mathrm{~nm}$ using spectrophotometer (Specord 250, Analytik Jena, Germany). A calibration curve $\left(\mathrm{y}=0.0057 \mathrm{x}+0.0146, R^{2}=0.9985\right)$ was constructed by preparing gallic acid solutions $(25-$ $400 \mathrm{mg} / \mathrm{L}$ ). The experiment was carried out in triplicate and the mean value of absorbance was calculated. Then TPC was determined in gallic acid equivalents (GAE) from the following formula: $\mathrm{A}=(\mathrm{C} \times \mathrm{V}) / \mathrm{m}$, where, $\mathrm{A}$ denote total phenolic content of extract equivalent to gallic acid, $\mathrm{C}$ is the concentration of the gallic acid obtained from calibration curve $(\mathrm{mg} / \mathrm{mL}), \mathrm{V}$ denote volume of the extract $(\mathrm{mL})$ and $\mathrm{m}$ is the plant extract weight $(\mathrm{g})$.

\section{Determination of flavonoid content}

Total flavonoid content was determined using aluminum chloride $\left(\mathrm{AlCl}_{3}\right)$ [33]. $1 \mathrm{ml}$ of MECC $(100 \mu \mathrm{g} / \mathrm{mL})$ was taken and mixed with $2 \mathrm{~mL}$ of methanol. Then $0.1 \mathrm{~mL}$ of $10 \% \mathrm{AlCl}_{3}$ (w/v in distilled water), Na-K tartrate (1 M) solution and $2.8 \mathrm{~mL}$ distilled water was sequentially added to the extract solution. Then the mixture was vigorously shaken by vortex mixture (Clifton CM-1, Camlab, UK) and incubated at room temperature for $30 \mathrm{~min}$. The absorbance of the solution was taken using spectrophotometer at $415 \mathrm{~nm}$. The experiment was carried out in triplicate and the mean absorbance value was noted. The total flavonoid content was measured from the calibration curve of quercetin $(y=0.0165 x+0.1353$, $\left.R^{2}=0.9933\right)$ and expressed as $\mathrm{mg}$ of quercetin equivalent/g of plant extract.

\section{DPPH free radical scavenging assay}

To determine the scavenging effect of MECC on DPPH radical, a stock solution of $1.6 \mathrm{mg}$ extract in $0.4 \mathrm{~mL}$ methanol was prepared. The test solution was prepared at the concentration of $1.5625,3.125,6.25,12.5,25,50$, 100,200 and $400 \mu \mathrm{g} / \mathrm{mL}$ using methanol. A volume of $2 \mathrm{~mL}$ test solution was added to $2 \mathrm{~mL}$ of a methanol solution of DPPH $(0.1 \mathrm{mM})$. The mixture was properly mixed and kept in a dark place at room temperature for $30 \mathrm{~min}$. The absorbance of the solutions was read at $517 \mathrm{~nm}$ against blank. The experiment was carried out triplicate for each concentration. The percentage of inhibition of DPPH free radicals was calculated from following equation: \% inhibition $=[($ absorbance of blank absorbance of the sample)/absorbance of blank] $\times 100$. The scavenging capacity of ascorbic acid in the same concentration was determined similarly as standard [34]. The concentration at which the $50 \%$ DPPH free radicals were inhibited $\left(\mathrm{IC}_{50}\right)$ was calculated using GraphPad prism, Version 6.05.

\section{Acute toxicity test}

The animals were divided into control and three experimental groups $(n=5)$. MECC was orally administered at the dose of 1000,2000 and $4000 \mathrm{mg} / \mathrm{kg}$ to the experimental groups. The animals were kept in a distinct cage. After gavage, animals were provided free access to water 
ad libitum and food. Any allergic reactions (skin rashes, itching), discharges from eyes and mucous membrane, behavioral changes, food and water refusal, salivation, convulsion, tremors, diarrhea, and mortality of the animals were observed for 14 days. After the observation period, the body weight of surviving animals was recorded. Then, animals were sacrificed to examine any abnormalities and significant gross changes of the vital organs $[35,36]$.

\section{Pharmacological tests Hot plate test}

Hot plate test was performed to determine the central analgesic activity of MECC. The test was carried out using Eddy's hot plate (Kshitij Innovations, Haryana, India). Hot plate temperature was kept constant at $50 \pm$ $0.5{ }^{\circ} \mathrm{C}$. The mice were gently placed on the hot plate and jumping, withdrawal of paw(s), forepaw licking were considered as nociception. The mice were kept on the hot surface only for the $20 \mathrm{~s}$ (cut-off time) to avoid any thermal injury [37]. A latency was determined before treatment as a baseline for the study. After vehicle, standard drug morphine (i.p.) or MECC (p.o.) treatment the latency periods were measured at 30, 45, 60, 90 and $120 \mathrm{~min}$. The maximal possible effect (MPE) in \% of individual mice was measured by following formula: \% $\mathrm{MPE}=[$ (post-treatment latency - pre-treatment latency)/(cut-off time - pre-treatment latency) $] \times 100$.

\section{Tail immersion test}

The test was carried out based on the findings that morphine-like drugs extend the tail withdrawal time from hot water in mice [38]. Mice were gently restrained using 'Chux' and one to two $\mathrm{cm}$ of the tail was immersed into hot water set at $52 \pm 1{ }^{\circ} \mathrm{C}$. The latency between submersion and withdrawal of the tail was recorded and considered as the index of nociception. Mice that demonstrated withdrawal of tail between 1.5 and $3.5 \mathrm{~s}$ from the hot water were selected for the test. A 20s cut-off period was maintained to avoid tissue damage of tail of mice. The latency time was recorded before and after 30, 45, 60, 90 and $120 \mathrm{~min}$ of the vehicle, morphine (i.p.) or MECC (p.o.) treatment. The \% MPE was calculated from pre and post treatment latency as described in hot plate test.

\section{Acetic acid-induced writhing test}

The acetic acid-induced writhing test was conducted to determine the central and peripheral antinociceptive effect of MECC against chemical induced nociception. Mice were treated (i.p.) with $0.6 \%$ (v/v) acetic acid to induce writhing. Acetic acid was employed at the dose of $10 \mathrm{~mL} / \mathrm{kg}$ (b.w.) $30 \mathrm{~min}$ after vehicle or MECC and 15 min of diclofenac sodium (i.p.) administration. Mice were then placed in separate box. After 5 min of acetic acid treatment, the number of writhing was recorded for $30 \mathrm{~min}$ [39]. The writhing was defined by contraction of the abdomen, arching of back, twisting of the trunk and/ or pelvis ending with the elongation of limbs.

\section{Formalin-induced licking test}

A volume of $20 \mu \mathrm{l}$ of formalin (2.5\% formalin (0.92\% formaldehyde) prepared in saline) was injected into the subplantar region of the right hind paw of mice to induce pain. Formalin was injected 15 min after morphine and $30 \mathrm{~min}$ after vehicle or MECC treatment. Responses like licking, biting, lifting, shaking of right hind paw were considered as nociception. The nociceptive responses were measured 0 to 5 min (early phase) and 15 to $30 \mathrm{~min}$ (late phase) following formalin treatment, representing to the neurogenic and inflammatory pain responses respectively [40].

\section{Glutamate-induced paw licking and edema test}

Mice were injected with $20 \mu \mathrm{l}$ of $20 \mu$ mol glutamate (prepared in saline, $\mathrm{pH}$ 7.4) in the sub-plantar area of the right hind paw. Mice received vehicle or MECC and diclofenac sodium 30 and 15 min before glutamate injection respectively. The right hind paw thickness of mice was measured before glutamate challenge using digital slide caliper (M: 091552; Shanghai Shenhan Measuring Tools Co., Ltd, Shanghai, China). The licking was measured for $15 \mathrm{~min}$ after glutamate challenge and accounted as indicative of nociception. Then paw thickness of right hind paw of every mouse was measured again and the degree of edema $(\Delta)$ in $\mathrm{mm}$ was calculated from the following formula: $\Delta=$ (paw thickness after treatment - paw thickness before treatment) [41].

\section{Analysis of the possible mechanism of action of MECC}

Involvement of the opioid system In order to determine the participation of opioid system in the pain inhibition effect of MECC naloxone was intraperitoneally administered 15 min before $\operatorname{MECC}$ (50, 100, 200 and $400 \mathrm{mg} / \mathrm{kg}$ ) or morphine sulfate administration in the hot plate and tail immersion test [42]. The latencies of the hot plate and tail immersion were sequentially recorded at pre-treatment, 30, 45, 60, 90, 120 min of after administration of MECC or morphine and assembled with the result of the hot plate and tail immersion test respectively. The same cut-off period of the $20 \mathrm{~s}$ was maintained for any thermal injury.

\section{Involvement of the cyclic guanosine monophosphate (cGMP) pathway}

Mice were pre-treated with methylene blue (MB), a nonspecific guanylylcyclase/NO inhibitor to verify the possible involvement of cGMP in the pain inhibition action 
of MECC. MB (20 $\mathrm{mg} / \mathrm{kg})$ was administered (i.p.) $15 \mathrm{~min}$ before the employment of effective doses (100, $200,400 \mathrm{mg} / \mathrm{kg}$ ) of MECC. After $30 \mathrm{~min}$ of treatment, animals were intraperitoneally administered $0.6 \%(\mathrm{v} / \mathrm{v})$ acetic acid at the dose of $10 \mathrm{~mL} / \mathrm{kg}$ to induce writhing. The nociceptive behavior was recorded for $30 \mathrm{~min}$, starting after $5 \mathrm{~min}$ of acetic acid treatment. The abdominal writhing syndrome was counted as an indication of nociceptive behavior $[43,44]$.

\section{Involvement of the ATP-sensitive $\mathrm{K}^{+}$channel pathway}

The participation of $\mathrm{K}^{+}$channel in the antinociceptive action of the effective doses of MECC (100, 200 and $400 \mathrm{mg} / \mathrm{kg}$ was evaluated to the groups of mice, pretreated with glibenclamide, an ATP-sensitive $\mathrm{K}^{+}$channel inhibitor. Glibenclamide was intraperitoneally administered at the dose of $10 \mathrm{mg} / \mathrm{kg} 15 \mathrm{~min}$ before the treatment of MECC. After $30 \mathrm{~min}$ of above treatments, the mice of each group were challenged with $0.6 \%$ acetic acid (i.p.) to induce writhing. After $5 \mathrm{~min}$ of an acetic acid challenge, the number of writhing was noted for $30 \mathrm{~min}$ as an indication of nociceptive response [44, 45].

\section{Statistical analysis}

Data are presented as mean \pm standard error of mean (SEM). Statistical analysis of the results was performed using one-way analysis of variance (ANOVA). The significance of differences between groups was tested by Dunnett's or Bonferroni's test, as appropriate and $p<$ 0.05 values were considered as significant. SPSS 22 software was used for performing the statistical analysis. $\mathrm{IC}_{50}$ values were calculated using GraphPad prism (version 6.01) software.

\section{Results}

\section{Phytochemical analysis}

Phytochemical analysis of the crude methanol extract of C. cristata confirmed the presence of carbohydrates, alkaloids, flavonoids, tannins, steroids, proteins, saponins, glycosides and resins. The major phytochemical composition of MECC was further confirmed by TLC analysis. TLC fingerprinting of MECC (Fig. 1) indicate the presence of flavonoids (yellow or orange spots), phenolics (blue fluorescence spots), steroids (purple spots), glycosides (dark-violet after applying spray reagents) and alkaloids (pink spots). The comparison of $R_{f}$ values between standard marker and extract spots are presented in Table 1. From the quantitative analysis of MECC, total phenolic and flavonoid content were estimated as $45.21 \pm 1.86 \mathrm{mg}_{\mathrm{GAE}} / \mathrm{g}_{\text {extract }}$ and $66.69 \pm 2.14 \mathrm{mg} \mathrm{QE} / \mathrm{g}_{\text {extract }}$ respectively. In DPPH assay the extract showed dosedependent free radical scavenging activity (Fig. 2). The antioxidant activity of ascorbic acid and MECC in DPPH assay was estimated with the $\mathrm{IC}_{50}$ value of $5.14 \pm$ $0.08 \mu \mathrm{g} / \mathrm{mL}$ and $76.34 \pm 2.36 \mu \mathrm{g} / \mathrm{mL}$ respectively.

\section{Acute toxicity}

Oral administration of MECC at $1000-4000 \mathrm{mg} / \mathrm{kg}$ doses did not cause any mortality as well as allergic reactions, salivation, convulsion, tremors, diarrhea or behavioral changes during the observation period. In addition, no statistically significant gross changes or abnormality of the vital organs of the mice were observed between control and experimental groups (Table 2).

\section{Hot plate test}

Oral treatment of MECC in mice caused a significant $(p<0.001)$ increase of latency period in hot plate test at all experimental doses compared to control group (Fig. 3). The effect was maximum $(14.79 \pm 0.41 \mathrm{~s})$ at $400 \mathrm{mg} / \mathrm{kg}$ and dose related. The highest reaction time against thermal stimuli for 50, 100 and $200 \mathrm{mg} /$ $\mathrm{kg}$ of MECC was $11.24 \pm 0.23,12.19 \pm 0.61,13.54 \pm$ 0.39 s respectively. MECC produced significant $(p<$ $0.001) \% \mathrm{MPE}$ at the doses of 100, 200 and $400 \mathrm{mg} /$ $\mathrm{kg}$ throughout the observational period. The highest inhibition of thermal pain of MECC $(60.06 \%$ at the dose of $400 \mathrm{mg} / \mathrm{kg}$ ) and morphine $(66.27 \%)$ was observed at $90 \mathrm{~min}$. However, standard drug, morphine produced maximum latent time as well as \%MPE at all the observation period (Table 3 ). The mean latent period for naloxone was $6.72 \pm 0.15 \mathrm{~s}$. Naloxone could not produce any significant effect itself compared to control group $(6.65 \pm 0.26 \mathrm{~s})$. On the other hand, naloxone significantly $(p<0.001)$ reversed the activity of morphine and MECC at the all experimental doses.

\section{Tail immersion test}

MECC significantly increased hot water latency time in tail immersion test at the 100, 200 and $400 \mathrm{mg} / \mathrm{kg}$ test doses $(p<0.001)$ in a dose-dependent way (Fig. 4). MECC showed the highest latency on hot-water at the dose of $400 \mathrm{mg} / \mathrm{kg}$ throughout the experimental periods and the effect was maximum on the $90 \mathrm{~min}(6.73 \pm 0.29 \mathrm{~s})$. However, the significant maximal latency for the dose of 100 and $200 \mathrm{mg} / \mathrm{kg}$ of MECC was also found on $90 \mathrm{~min}$ as $4.48 \pm 0.39 \mathrm{~s}$ and $5.52 \pm 0.12 \mathrm{~s}$ respectively. MECC showed maximum $22.60 \%$ inhibition on the 90 min where morphine showed $56.30 \%$ inhibition (latency $12.48 \pm 0.50 \mathrm{~s}$ ) on the $60 \mathrm{~min}$ of the experimental period. The experimental doses of MECC produced significant $(p<0.001) \% \mathrm{MPE}$ at different observation period (Table 4). Morphine produced maximum latency as well as \%MPE at all the experimental periods $(p<0.001)$. The reversal effect of naloxone was also observed. Naloxone significantly $(p<0.01)$ antagonized the pain inhibition activity of morphine and MECC at the doses of 200 and $400 \mathrm{mg} / \mathrm{kg}$. 


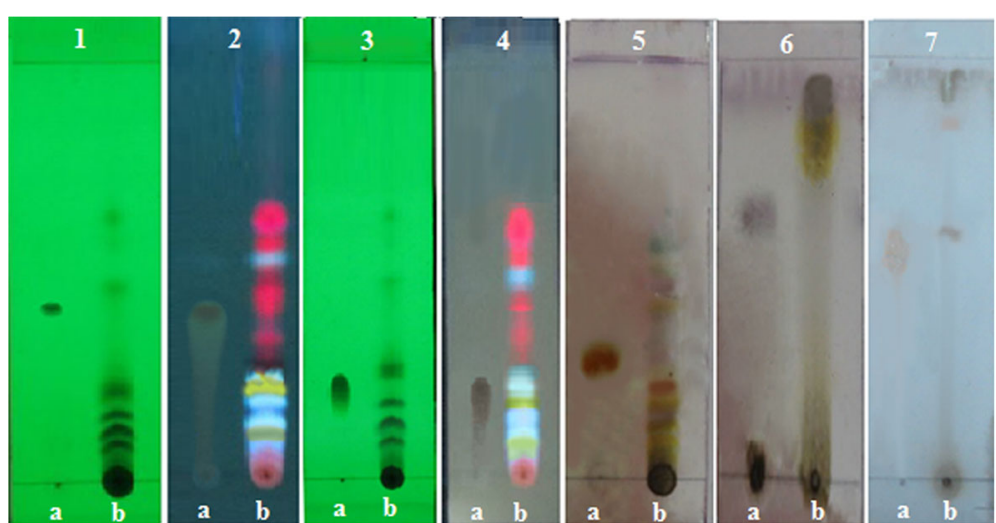

Fig. 1 Thin layer chromatograms of methanol extract of C. cristata (MECC). Experiment 1- (at 254 nm, a: quercetin, b: MECC), 2-(at 356 nm, a: quercetin, b: MECC) for flavonoids (orange, yellow spots); 3 - (at $254 \mathrm{~nm}$, a: gallic acid, b: MECC), 4- (at $356 \mathrm{~nm}$, a: gallic acid, b: MECC) for phenolics (fluorescence blue spots); 5 - after spray of $1 \%$ vanillin- $\mathrm{H}_{2} \mathrm{SO}_{4}$ reagent (a: stigmasterol, b: $\mathrm{MECC}$ ) for steroids (purple spots); 6- after spray of $\mathrm{H}_{2} \mathrm{SO}_{4}$ (a: digoxin, b: $\mathrm{MECC}$ ) for glycosides (dark-violet spots); 7 - after spray of Dragendroff's reagent (a: atropine, b: MECC) for alkaloids (light pink spots)

\section{Acetic acid-induced writhing test}

MECC at the doses of 100,200 and $400 \mathrm{mg} / \mathrm{kg}$ and diclofenac sodium significantly $(p<0.001)$ reduced the number of writhing induced by acetic acid compared to control group in mice (Table 5). Oral administration of MECC caused the highest reduction of the number of writhing $(26.50 \pm 1.55)$ at the doses of $400 \mathrm{mg} / \mathrm{kg}$. The highest inhibition of writhing of MECC was $55.76 \%$ compared to the control group and the percentage of inhibition of writhing was dose dependent. Standard drug (diclofenac sodium) caused a minimum number of writhing (18.80 \pm 1.02$)$ and showed the maximum inhibition of $68.61 \%$.

\section{Formalin-induced licking}

MECC produced marked inhibition $(p<0.001)$ of formalin-induced licking at the doses of 100, 200, $400 \mathrm{mg} / \mathrm{kg}$ in the early phase and at all the test doses in the late phase compared to control group (Fig. 5). The lowest spent time in licking both in early $(90.78 \pm 3.61 \mathrm{~s})$ and late phase $(75.10 \pm 4.46 \mathrm{~s})$ was observed at the dose

Table 1 Phytochemical analysis of MECC by TLC

\begin{tabular}{lllc}
\hline Phytochemicals & Color & Retention factor $\left(R_{f}\right)$ & \\
\cline { 3 - 4 } & & Extract & Standard \\
\hline Flavonoids & Yellow, orange $^{\mathrm{a}}$ & $1.02,0.20$ & 0.41 \\
Phenolics & blue fluroscence $^{\mathrm{a}}$ & $0.04,0.10,0.14,0.18,0.47$ & 0.22 \\
Steroids & Purple $^{\mathrm{b}}$ & $0.12,0.13,0.16$ & 0.34 \\
Glycosides & Dark-violet $^{\mathrm{b}}$ & 0.94 & 0.60 \\
Alkaloids & Light pink $^{\mathrm{b}}$ & $0.58,0.83$ & 0.54
\end{tabular}

$\mathrm{R}_{\mathrm{f}}$ values are the mean of two chromatograms

a Represents the color was observed under the visible or UV light

${ }^{b}$ Represents the color was observed after applying the appropriate spray

reagent. The standard for flavonoids, phenolics, steroids, glycosides and

alkaloids was quercetin, gallic acid, stigmasterol, digoxin, and

atropine respectively of $400 \mathrm{mg} / \mathrm{kg}$ compared to other doses of MECC where morphine caused minimum licking in mice from early phase $(46.53 \pm 4.05 \mathrm{~s})$ to late phase $(4.82 \pm 0.84 \mathrm{~s})$. The inhibition response of MECC was dose dependent in both phases. Besides, the late phase licking inhibition of the test by morphine and MECC was more prominent. MECC and morphine exerted the highest inhibition of licking by 54.50 and $97.08 \%$ respectively in the late phase.

\section{Glutamate-induced paw licking and edema}

The treatment of diclofenac sodium and 100, 200 and $400 \mathrm{mg} / \mathrm{kg}$ doses of MECC significantly $(p<0.001)$ decreased the glutamate-induced paw licking as well as paw edema in mice (Fig. 6). The reduction of paw licking time and edema by MECC in mice was dose reliant as stronger at $400 \mathrm{mg} / \mathrm{kg}(69.32 \pm 4.22 \mathrm{~s}$ and $0.48 \pm$ $0.05 \mathrm{~mm}$ respectively) compared to control group

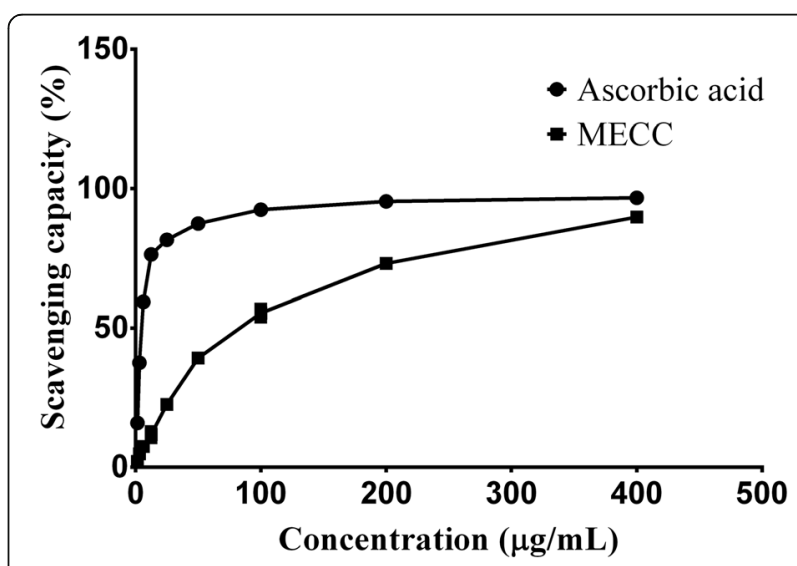

Fig. 2 DPPH free radical scavenging capacity (\%) of ascorbic acid and methanol extract of $C$. cristata at various concentrations $(\mu \mathrm{g} / \mathrm{mL})$. Each data point represents mean $\pm \operatorname{SEM}(n=3)$ 
Table 2 Effect of oral administration of MECC on gross changes to the vital organs of mice

\begin{tabular}{|c|c|c|c|c|c|c|}
\hline \multirow[t]{2}{*}{ Treatment } & \multicolumn{6}{|c|}{$\begin{array}{l}\text { Organ weight (g) } \\
\text { (Organ body index in \%) }\end{array}$} \\
\hline & Body weight & Heart & Kidneys & Liver & Lungs & Spleen \\
\hline Vehicle & $22.04 \pm 0.25$ & $0.15 \pm 0.01(0.66)$ & $0.38 \pm 0.01(1.72)$ & $1.32 \pm 0.02(6.01)$ & $0.23 \pm 0.02(1.03)$ & $0.10 \pm 0.01(0.46)$ \\
\hline MECC (1000 mg/kg) & $21.28 \pm 0.16$ & $0.11 \pm 0.01(0.52)$ & $0.32 \pm 0.02(1.48)$ & $1.33 \pm 0.13(6.23)$ & $0.18 \pm 0.01(0.86)$ & $0.07 \pm 0.01(0.35)$ \\
\hline MECC (2000 mg/kg) & $23.39 \pm 0.48$ & $0.18 \pm 0.01(0.79)$ & $0.44 \pm 0.03(1.85)$ & $1.79 \pm 0.12(7.78)$ & $0.27 \pm 0.02(1.14)$ & $0.15 \pm 0.02(0.63)$ \\
\hline MECC (4000 mg/kg) & $23.27 \pm 0.58$ & $0.17 \pm 0.01(0.89)$ & $0.41 \pm 0.03(1.74)$ & $1.76 \pm 0.19(7.52)$ & $0.29 \pm 0.04(1.23)$ & $0.14 \pm 0.02(0.60)$ \\
\hline
\end{tabular}

Each value is presented as the mean \pm SEM $(n=5)$. MECC $=$ Methanol extract of C. cristata, organ body index $(\%)=($ weight of organ/weight of body) $/ 100 . P$ is not $\leq 0.05$, compared to control group (Dunnett's test)

$(185.33 \pm 4.20 \mathrm{~s}$ and $0.94 \pm 0.03 \mathrm{~mm}$ respectively). MECC produced the highest reduction of glutamate-induced paw licking and edema at the dose of $400 \mathrm{mg} / \mathrm{kg}$ by 62.59 and $49.14 \%$ respectively. However, diclofenac sodium showed the maximum inhibition of paw licking and edema by 74.05 and $65.81 \%$ respectively.

\section{Involvement of the cyclic guanosine monophosphate (cGMP) pathway}

As presented in Fig. 7, MECC (100, 200 and $400 \mathrm{mg} / \mathrm{kg}$ ) and methylene blue $(20 \mathrm{mg} / \mathrm{kg})$ in alone caused significant inhibition of number of writhing (38.90 \pm 3.77 , $33.20 \pm 2.75,23.50 \pm 2.17$ and $37.70 \pm 1.23$ respectively) compared to control group $(53.60 \pm 4.31)$. The MB treatment with 100, 200 and $400 \mathrm{mg} / \mathrm{kg}$ doses of MECC amplified the antinociceptive activity by reduction of the number of writhing $(31.40 \pm 4.80,23.20 \pm 2.84,11.70 \pm$
1.06 respectively). The methylene blue and MECC $(400 \mathrm{mg} / \mathrm{kg})$ together significantly $(p<0.05)$ enhanced the antinociceptive effect compared to the treatment with methylene blue and MECC (400 mg/kg) alone.

\section{Involvement of the ATP-sensitive $\mathrm{K}^{+}$channel pathway}

The action of glibenclamide and MECC on the acetic acid-induced writhing response in mice are presented in Fig. 8. Glibenclamide did not cause any significant alteration of the number of writhing response $(59.60 \pm 1.69)$ compared to control group $(60.10 \pm 2.03)$. MECC produced significant inhibition of writhing response at all the tested doses $(p<0.001)$. However, glibenclamide reversed the antinociceptive action when administered with MECC (100, 200, $400 \mathrm{mg} / \mathrm{kg})$. The reversal effect was significant $(p<0.05)$ for the glibenclamide plus MECC $100(45.80 \pm 0.51)$ as well as glibenclamide plus

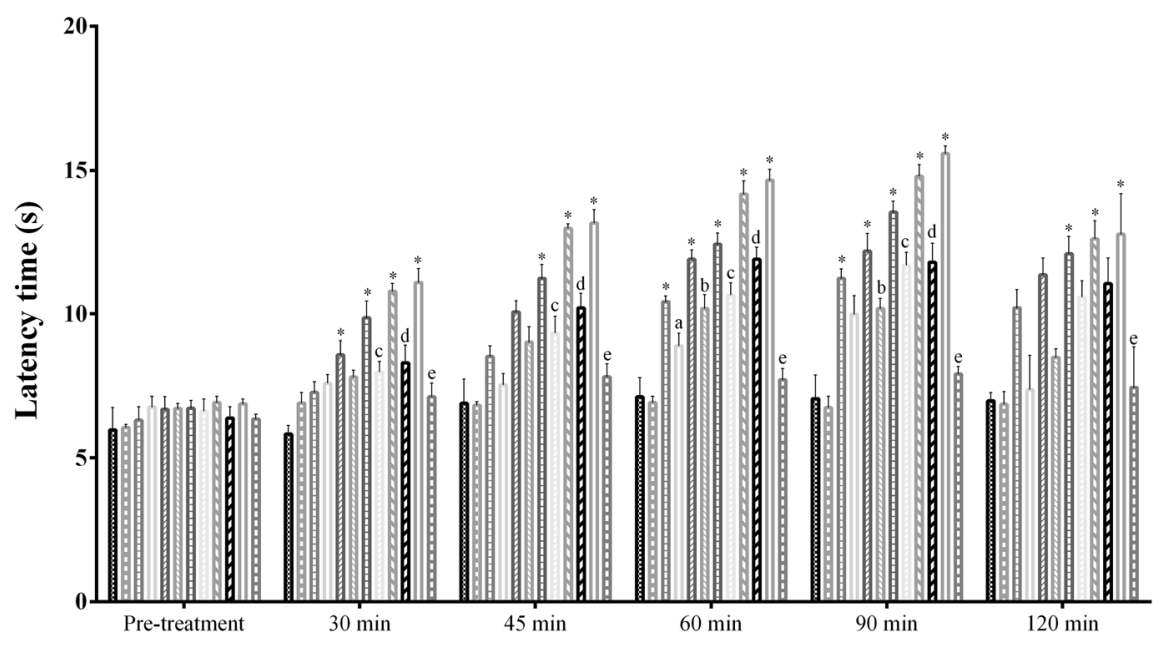

Observation period

\begin{tabular}{|c|c|c|c|}
\hline & Vehicle $(10 \mathrm{~mL} / \mathrm{Kg})$ & MECC (100 mg/Kg) & $\$ \operatorname{MECC}(400 \mathrm{mg} / \mathrm{Kg})$ \\
\hline & $\mathrm{NLX}(2 \mathrm{mg} / \mathrm{Kg})$ & $\mathbb{M E C C}(100 \mathrm{mg} / \mathrm{Kg})+\mathrm{NLX}(2 \mathrm{mg} / \mathrm{Kg})$ & $\mathbb{M E C C}(400 \mathrm{mg} / \mathrm{Kg})+\mathrm{NLX}(2 \mathrm{mg} / \mathrm{Kg})$ \\
\hline & $\mathrm{MECC}(50 \mathrm{mg} / \mathrm{Kg})$ & 回 MECC (200 mg/Kg) & III Morphine (5 mg/Kg) \\
\hline & $\operatorname{MECC}(50 \mathrm{mg} / \mathrm{Kg})+\mathrm{NLX}(2 \mathrm{mg} / \mathrm{Kg})$ & MECC $(200 \mathrm{mg} / \mathrm{Kg})+\mathrm{NLX}(2 \mathrm{mg} / \mathrm{Kg})$ & Morphine $(5 \mathrm{mg} / \mathrm{Kg})+\mathrm{NLX}(2 \mathrm{mg} / \mathrm{K}$ \\
\hline
\end{tabular}

Fig. 3 Effect of methanol extract of $C$. cristata in hot plate test. Data are presented as the mean \pm SEM $(n=5)$. MECC $=$ Methanol extract of $C$. cristata; NLX = Naloxone. ${ }^{*}$ represents $p<0.001$ compared with the control group (Dunnett's test). ${ }^{a}$ b, c, d, e represents $p<0.001$, compared with the MECC 50, MECC 100, MECC 200, MECC 400, morphine, group respectively (Bonferroni's test) 
Table 3 The percentage of maximum possible effect (\%MPE) of MECC in hot plate test

\begin{tabular}{|c|c|c|c|c|c|c|}
\hline \multirow[t]{2}{*}{ Treatment } & \multirow{2}{*}{$\begin{array}{l}\text { Dose } \\
\text { (mg/ } \\
\mathrm{kg})\end{array}$} & \multicolumn{5}{|l|}{$\% \mathrm{MPE}$} \\
\hline & & $30 \mathrm{~min}$ & $45 \mathrm{~min}$ & $60 \mathrm{~min}$ & $90 \mathrm{~min}$ & $120 \mathrm{~min}$ \\
\hline Vehicle & - & $-2.49 \pm 6.47$ & $5 \pm 9.24$ & $7.44 \pm 5.44$ & $5.17 \pm 11.70$ & $5.73 \pm 6.69$ \\
\hline NLX & 2 (i.p.) & $6.06 \pm 2.50$ & $5.51 \pm 1.26$ & $6.11 \pm 2.00$ & $4.98 \pm 2.68$ & $5.73 \pm 3.64$ \\
\hline MECC & 50 & $6.97 \pm 1.42$ & $15.66 \pm 4.85$ & $29.61 \pm 3.22^{*}$ & $36.02 \pm 1.36^{*}$ & $28.39 \pm 4.16$ \\
\hline MECC & 100 & $14.19 \pm 3.03$ & $25.32 \pm 2.50^{*}$ & $39.07 \pm 1.87^{*}$ & $40.98 \pm 5.99^{*}$ & $35.26 \pm 3.02^{*}$ \\
\hline MECC & 200 & $23.64 \pm 3.90^{*}$ & $34.04 \pm 3.14^{*}$ & $43.02 \pm 2.17^{*}$ & $51.43 \pm 2.24^{*}$ & $40.01 \pm 5.62^{*}$ \\
\hline MECC & 400 & $29.62 \pm 1.23^{*}$ & $46.24 \pm 1.89^{*}$ & $55.36 \pm 3.67^{*}$ & $60.06 \pm 3.28^{*}$ & $43.48 \pm 4.83^{*}$ \\
\hline Morphine & 5 (i.p.) & $32.07 \pm 3.64^{*}$ & $47.89 \pm 3.68^{*}$ & $59.14 \pm 3.26^{*}$ & $66.27 \pm 2.18^{*}$ & $45.24 \pm 10.25^{*}$ \\
\hline
\end{tabular}

Each value is presented as the mean \pm SEM $(n=5)$. MECC $=$ Methanol extract of $C$. cristata; NLX $=$ Naloxone. ${ }^{*}$ represents $p<0.001$ compared with the control group (Dunnett's test)

$400 \mathrm{mg} / \mathrm{kg}(34.40 \pm 1.80)$ treatment, compared to the treatments with MECC $100(39.10 \pm 1.76)$ and $400 \mathrm{mg} /$ $\mathrm{kg}(24.60 \pm 2.16)$ alone respectively.

\section{Discussion}

The current investigation demonstrates that oral treatment of MECC inhibited thermal and chemical-induced pain threshold and produced dose-dependent central and peripheral antinociceptive effect in different pain models. In acute toxicity study, no mortality, allergic reactions, salivation, convulsion, tremors, diarrhea, behavioral and gross changes of vital organs in mice after the administration of 10-fold higher dose than the maximum experimental dose of MECC suggest that MECC was non-toxic at our experimental doses.

The significant $(p<0.001)$ increase of latency time and inhibition of thermal pain threshold of mice in the hot plate (Fig. 3) and tail immersion (Fig. 4) tests at different doses indicate that MECC has a profound central antinociceptive effect. These tests are widely used to evaluate the central antinociceptive effect of drugs and the tail withdrawal response determines the antinociceptive effect of centrally acting analgesics only [46]. Therefore, the antinociceptive activity of MECC in tail immersion

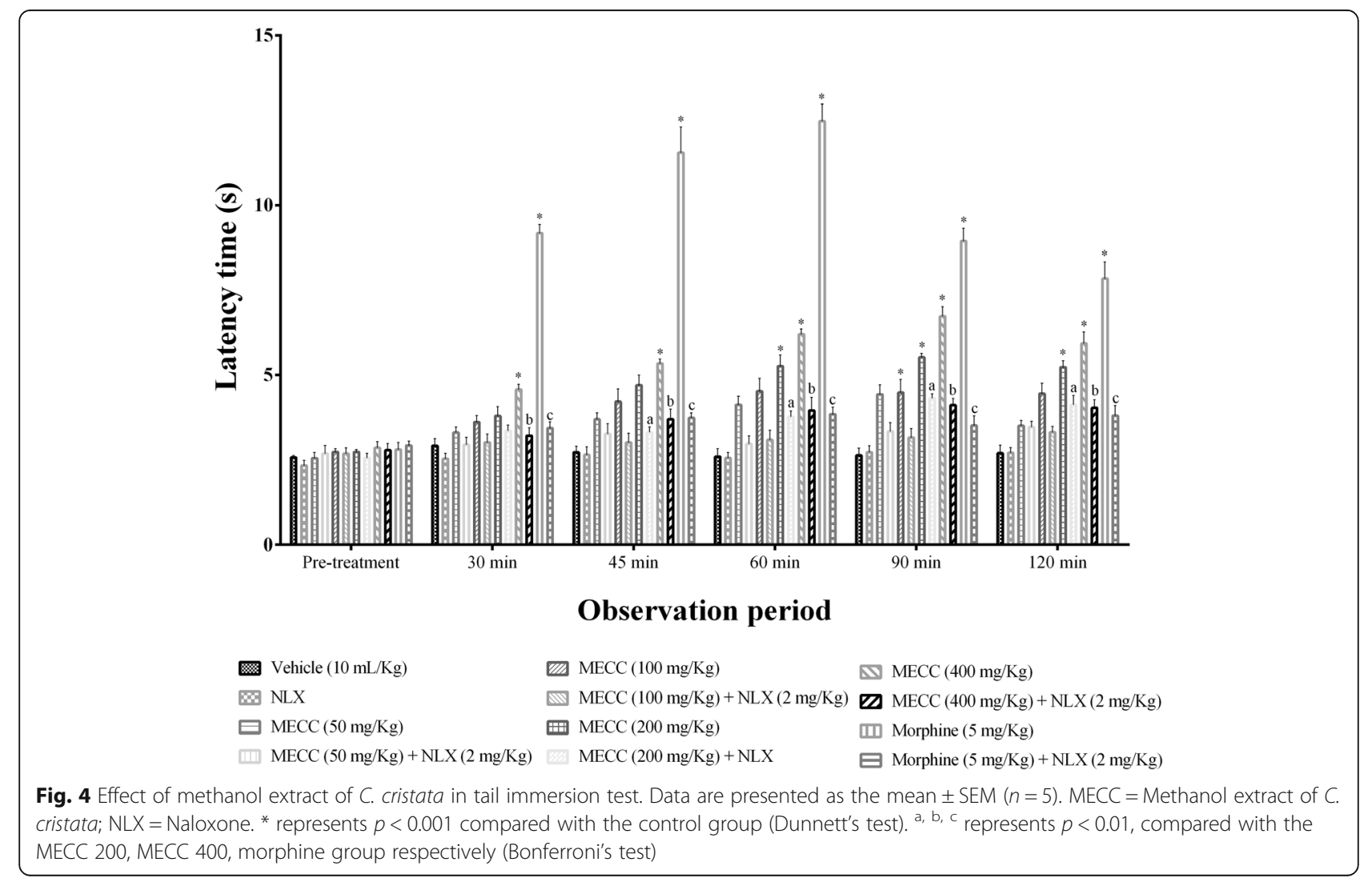


Table 4 The percentage of maximum possible effect (\%MPE) of MECC in tail immersion test

\begin{tabular}{|c|c|c|c|c|c|c|}
\hline \multirow[t]{2}{*}{ Treatment } & \multirow[t]{2}{*}{ Dose (mg/kg) } & \multicolumn{5}{|l|}{ \%MPE } \\
\hline & & $30 \mathrm{~min}$ & $45 \mathrm{~min}$ & $60 \mathrm{~min}$ & $90 \mathrm{~min}$ & $120 \min$ \\
\hline Vehicle & - & $1.95 \pm 1.15$ & $0.87 \pm 0.83$ & $0.10 \pm 1.44$ & $0.32 \pm 1.07$ & $0.71 \pm 1.20$ \\
\hline NLX & 2 (i.p.) & $1.12 \pm 1.18$ & $1.74 \pm 1.99$ & $1.25 \pm 1.33$ & $2.43 \pm 1.42$ & $2.09 \pm 0.74$ \\
\hline MECC & 50 & $4.35 \pm 0.57$ & $6.55 \pm 0.97$ & $8.99 \pm 1.60$ & $10.77 \pm 1.38^{*}$ & $5.40 \pm 1.56$ \\
\hline MECC & 100 & $5.04 \pm 1.18$ & $8.57 \pm 2.17$ & $10.28 \pm 2.11$ & $10.05 \pm 2.31^{*}$ & $9.88 \pm 1.88$ \\
\hline MECC & 200 & $6.15 \pm 1.56$ & $11.36 \pm 1.65$ & $14.65 \pm 1.71^{*}$ & $16.12 \pm 0.58^{*}$ & $14.39 \pm 1.32^{*}$ \\
\hline MECC & 400 & $9.97 \pm 1.02^{*}$ & $14.46 \pm 0.95^{*}$ & $19.51 \pm 0.56^{*}$ & $22.60 \pm 1.33^{*}$ & $17.91 \pm 1.79^{*}$ \\
\hline Morphine & 5 (i.p.) & $36.98 \pm 1.39 *$ & $50.92 \pm 4.19^{*}$ & $56.30 \pm 2.72^{*}$ & $35.65 \pm 2.07^{*}$ & $29.17 \pm 3.41^{*}$ \\
\hline
\end{tabular}

Each value is presented as the mean $\pm \operatorname{SEM}(n=5)$. MECC $=$ Methanol extract of $C$. cristata; NLX $=$ Naloxone. * represents $p<0.001$, compared with the control group (Dunnett's test)

test further approve the outcome of hot plate test. Besides, hot plate and tail immersion evaluate $\mu_{1^{-}}, \delta_{1^{-}} \kappa_{3}$ and $\sigma_{2}$ - opioid receptors mediated supraspinal reflex and $\mu_{2^{-}}, \kappa_{1}-$ and $\delta_{2}$ - opioid receptors mediated spinal reflexes respectively [47-50]. Our findings indicate that central antinociceptive effect of MECC is due to its action on supraspinal as well as the spinal system. Naloxone significantly reversed the antinociceptive effect of MECC at different doses level in both heat-induced pain models. This action further confirms the involvement of opioid receptors mediated central antinociceptive activity of MECC.

The writhing nociceptive response was significantly $(p<$ 0.001 ) inhibited by MECC in acetic acid-induced writhing test (Table 5). The test is widely used for the determination of central and peripheral antinociceptive activity of new substances [51]. Intraperitoneal treatment of acetic acid increases the degree of endogenous prostaglandins (PGs), serotonin, histamine, bradykinin, substance P, cyclooxygenase (COX), lipooxygenase (LOX) and cytokines such as IL-8, IL-1 $\beta$, and TNF- $\alpha$ in the peripheral fluid tissue. These endogenous inflammatory mediators and cytokines then enter into the dorsal horn of central nervous system and stimulate the primary afferent nociceptors [52]. This action results in the induction of inflammatory pain and writhing syndrome [53]. Therefore, significant inhibition of acetic acid-induced writhing by MECC can

Table 5 Effect of methanol extract of C. cristata in the acetic acid-induced writhing test

\begin{tabular}{llcl}
\hline Treatment & Dose $(\mathrm{mg} / \mathrm{kg})$ & Number of Writhing & \% Inhibition \\
\hline Vehicle & - & $59.90 \pm 1.03$ & - \\
Diclofenac sodium & 10 (i.p.) & $18.80 \pm 1.02^{*}$ & 68.61 \\
MECC & 50 & $51.70 \pm 1.62$ & 13.69 \\
MECC & 100 & $36.60 \pm 1.77^{*}$ & 38.89 \\
MECC & 200 & $34.90 \pm 1.13^{*}$ & 41.74 \\
MECC & 400 & $26.50 \pm 1.55^{*}$ & 55.76 \\
\hline
\end{tabular}

Each value is presented as mean $\pm \operatorname{SEM}(n=5), \operatorname{MECC}=$ Methanol extract of $C$. cristata. * represents $p<0.001$ compared with the control group (Dunnett's Test) be attributed to the suppression of release of peripheral inflammatory mediators as well as interruption of the signal transduction of primary afferent nociceptors.

The pain induced by formalin in mice paw is mediated by two distinct pathways. First, the early phase (immediately after formalin injection), characterized by neurogenic pain, is induced due to direct stimulation of sensory afferent fibers as well as activation of C-fibers. Bradykinin and substance $\mathrm{P}$ are also involved in the inducement of nociception in this phase. Second, the late phase (15 min after formalin injection), where the inflammatory pain is produced by the action of prostaglandins (PGs), bradykinin, serotonin and histamine-like inflammatory mediators in peripheral tissues $[54,55]$. In addition, formalin induced late phase pain is also caused by the functional changes in the dorsal horn of the spinal cord [56]. The result of the formalin-induced paw licking test (Fig. 5) shows that morphine and MECC significantly $(p<0.001)$ inhibited the nociception of both phases. The inhibition was dose dependent and more prominent in the late phase. Central analgesics (opioids) inhibit both phases whereas peripheral analgesics (aspirin, hydrocortisone) inhibit mainly the late phase of formalin-induced paw-licking in mice [57-59]. Therefore, significant inhibition of both phase paw lickings in formalin test further indicates the central pain prevention activity of MECC and supports the outcome of the hot plate and tail immersion tests. Besides, the late phase paw-licking deterrence suggests the inhibition of the inflammatory mediators, which was observed in the acetic acid-induced writhing test.

The glutamate-induced paw licking nociception is mediated via NMDA (N-methyl-D-aspartate) receptors while edema formation is accompanied by non-NMDA receptors (AMPA, Kainate) in peripheral, supraspinal and spinal sites. Glutamate release substance P and IL$1 \beta$, TNF- $\alpha$ like pro-inflammatory cytokines for the transmission of pain signals from peripheral nervous system to the dorsal horn of the central nervous system. Furthermore, the pro-inflammatory signals involve the 


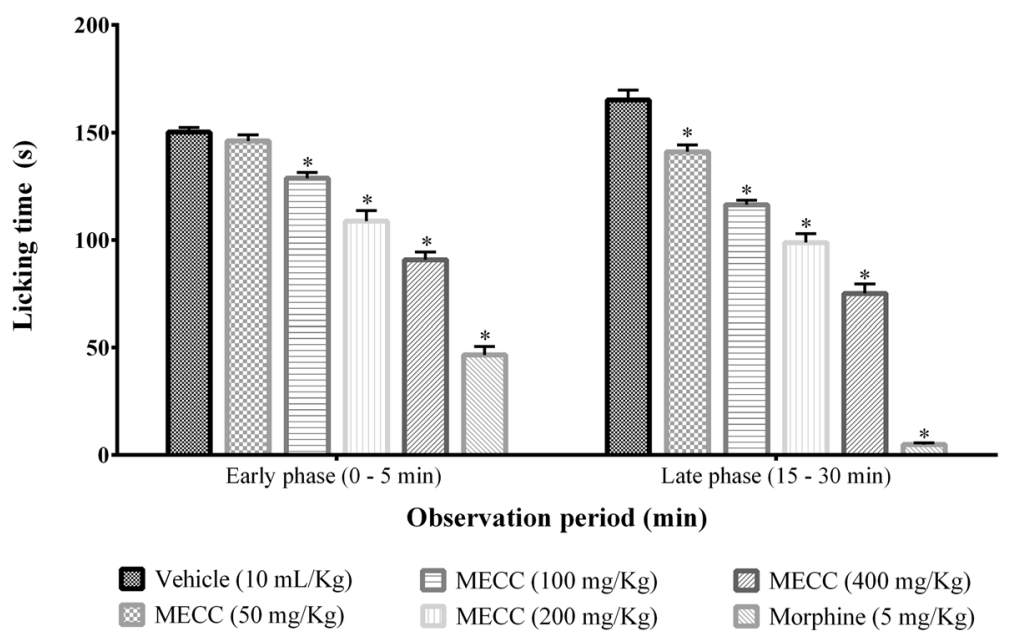

Fig. 5 Effect of methanol extract of C. cristata in formalin-induced paw licking test. Data are presented as mean \pm SEM $(n=5)$, MECC $=$ Methanol extract of C. cristata. ${ }^{*}$ represents $p<0.001$ compared with the control group (Dunnett's Test)

stimulation of TNF- $\alpha$, IL-1, IL-6 genes by nitric oxide synthase (NOS) and reactive oxygen species (ROS) [6062]. MECC significantly $(p<0.001)$ reduced glutamateinduced paw licking and edema (Fig. 6). The result suggests that MECC is involved in the suppression of NMDA, non-NMDA receptors as well as disruption of ROS, NOS mediated pro-inflammatory signals. Besides, C. cristata and its isolated compound, HA, have been reported to inhibit the ROS and NOS, IL-1 induced proinflammatory cytokine TNF- $\alpha$ respectively [63-66] which strongly suggests the association of NOS, ROS as well as TNF- $\alpha$ mediated pro-inflammatory signal interruption activity of MECC.

The present study examined the association of cGMP pathway in pain inhibition activity of MECC. It has been reported that $\mathrm{NO}$ associated nociceptive signal transduction is influenced by the cellular level of cGMP, where the concentration of cGMP in the intracellular level is controlled by the action of sGC (soluble guanylyl cyclase) [43]. The involvement of cGMP in MECC induced antinociception was evaluated by treating the mice with methylene blue (MB), a guanylyl cyclase inhibitor, before the inducement of acetic acid treated abdominal pain. The results indicated that (Fig. 7) methylene blue significantly enhanced the pain inhibition activity of MECC as well as inhibited the nociceptive response alone. $\mathrm{MB}$ interrupt the $\mathrm{NO}$ associated nociceptive signal transduction by the inhibition of the action of sGC as well as the availability of cGMP in intracellular level and promotes antinociceptive effect [43]. As MB pre-treatment enhanced the antinociceptive activity of MECC compared to the MECC alone, it can be suggested that pain inhibition action of MECC involves cGMP pathway. The outcomes of the present investigation also suggest the involvement of the ATP-sensitive $\mathrm{K}^{+}$channel pathway in the antinociception of MECC. Glibenclamide, an ATP-

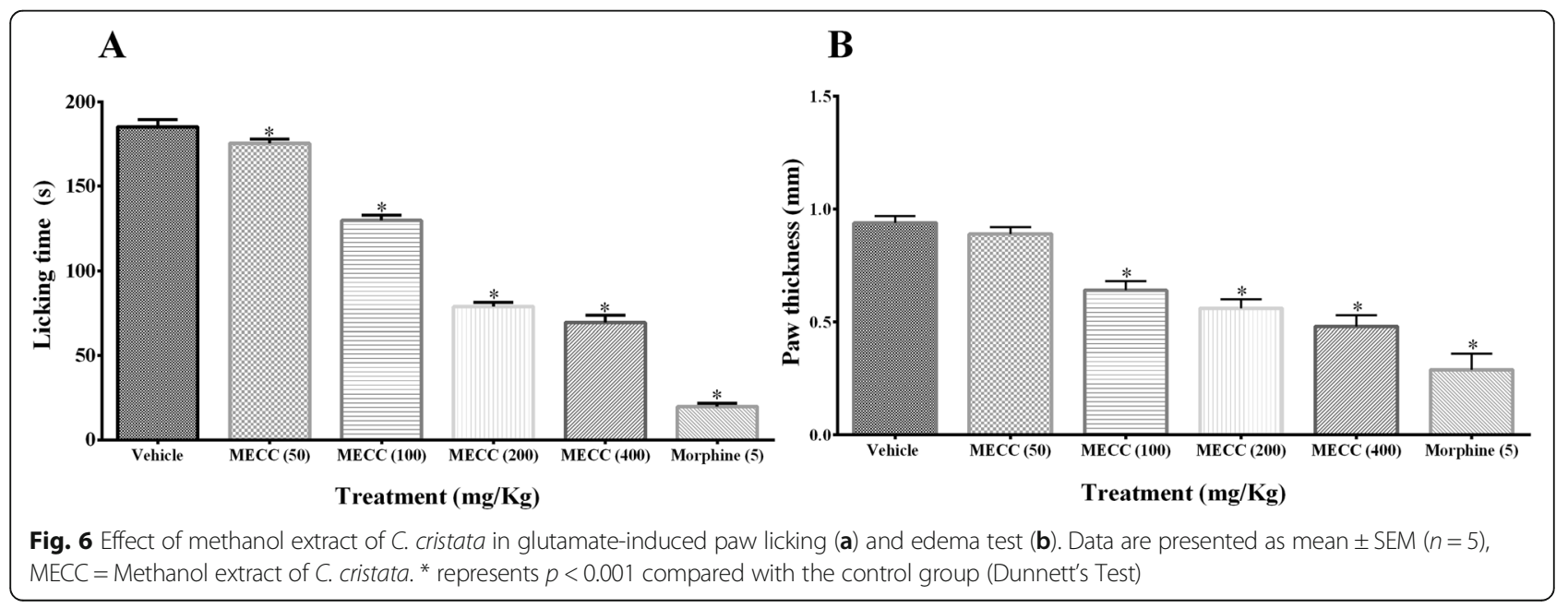




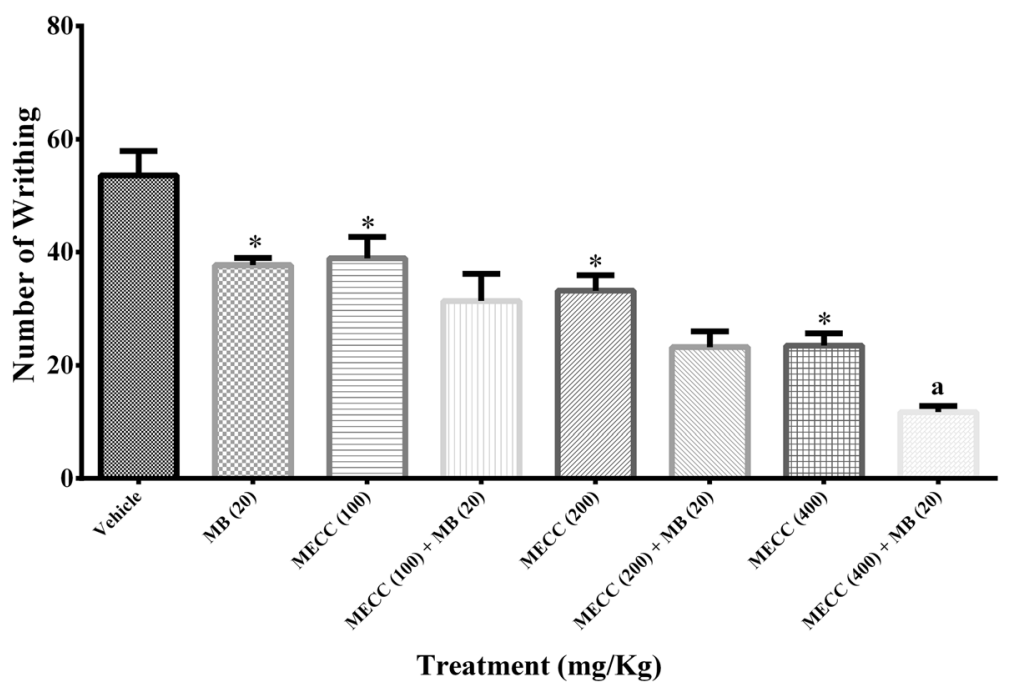

Fig. 7 Effect of methanol extract of C. cristata on the involvement of the cyclic guanosine monophosphate (cGMP) pathway. Data are presented as mean $\pm \operatorname{SEM}(n=5), \mathrm{MECC}=$ Methanol extract of $C$. cristata. MB = methylene blue. * represents $p<0.001$ compared with the control group (Dunnett's Test). ${ }^{\text {a }}$ represents $p<0.05$ compared with the MECC 400 group (Bonferroni's test)

sensitive $\mathrm{K}^{+}$channel blocker, partly abolished the pain inhibition activity shown by MECC (Fig. 8). It has been reported that glibenclamide cause the blockade of ATPsensitive $\mathrm{K}^{+}$channel without affecting the voltage-gated and $\mathrm{Ca}^{2+}$ activated $\mathrm{K}^{+}$channels $[67,68]$. Therefore, the result indicates that antinociceptive action of MECC could be related to the subsequent efflux of $\mathrm{K}^{+}$ions by the opening of the ATP-sensitive $\mathrm{K}^{+}$channel as well as reduction of the membrane excitability by hyperpolarization and/or repolarization [69].

Phytochemical study of C. cristata reveals the presence of alkaloids, flavonoids, tannins, steroids, glycosides.
TLC analysis of MECC further confirms the presence of these phyto-compounds. The amount of total phenolic, flavonoid and antioxidant activity against DPPH free radicals of MECC was considerable. The NMDA signaling in the pain inducement is influenced by the free radicals [69]. Therefore, pain inhibition action of MECC could be partially credited to the action of MECC against free radicals. Plant containing flavonoids have been reported to inhibit the pro-inflammatory cytokines like TNF- $\alpha$, IL-6 [70]. Besides, the plant having alkaloids, flavonoids and tannins possess significant analgesic property [71-73]. Therefore, it can be suggested that

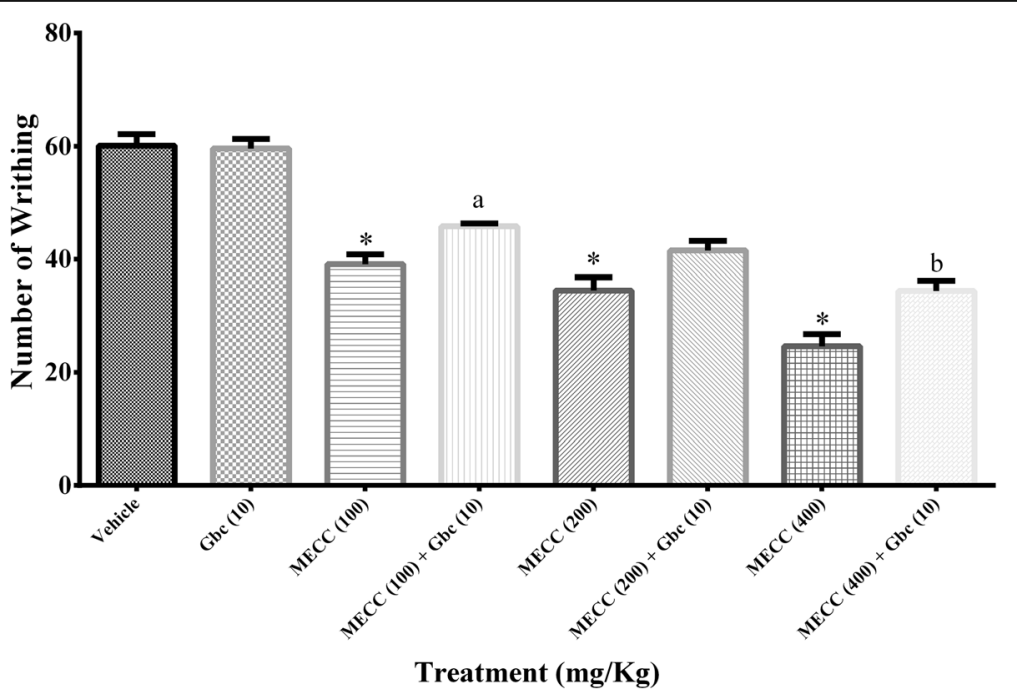

Fig. 8 Effect of methanol extract of C. cristata on the involvement of the ATP-sensitive $\mathrm{K}^{+}$channel pathway. Data are presented as mean \pm SEM $(n=5)$, MECC = Methanol extract of C. cristata. Gbc = glibenclamide. * represents $p<0.001$ compared with the control group (Dunnett's Test). ${ }^{\text {a, } b}$ represents $p<0.05$ compared with the MECC 100, MECC 400 group respectively (Bonferroni's test) 
phytochemicals, particularly phenolics, flavonoids, tannins and alkaloids present in MECC may contribute to its antinociceptive activity.

\section{Conclusion}

Considering the results of different pain models in mice, it can be suggested that crude methanol extract of C. cristata possess strong and dose-dependent antinociceptive activity. The effect is associated with opioid receptor, cGMP pathway, ATP-sensitive $\mathrm{K}^{+}$channel as well as suppression of peripheral mediators such as PGs, COX, LOX, NMDA, non-NMDA receptors. The outcomes justify the ethnomedicinal implication of C. cristata in different painful conditions such as headache, eye inflammations, sores, ulcers, skin eruption, wounds and body swelling. However, further studies regarding direct modulation of the nociceptive mediators and isolation of active principle(s) responsible for observed pharmacological actions are required to elucidate precise mechanisms of this plant. The findings of the present study suggest that $C$. cristata possibly contain potential bioactive molecules which could be used for the development of the analgesic lead compound.

\section{Abbreviations \\ AMPA: Alpha-amino-3-hydroxy-5-methylisoxazole-4-propionic acid; ANOVA: One-way analysis of variance; ATP: Adenosine triphosphate; AVMA: American Veterinary Medical Association; b.w.: Body weight; BPH: Benign prostate hyperplasia; CGMP: Cyclic guanosine monophosphate; COX: Cyclooxygenase; DPPH: 2,2-Diphenyl-1-picrylhydrazyl; GAE: Gallic acid equivalents; Gbc: Glibenclamide; HA: Hyaluronic acid; i.p.: Intraperitoneal; $I_{50}$ : Half maximal inhibitory concentration; icddr,b: International Center for Diarrhoeal Disease Research, Bangladesh; IL: Interleukin; IL-1 B: Interleukin-1 beta; LOX: Lipooxygenase; MB: Methylene blue; MECC: Methanol extract of Celosia cristata; MPE: Maximal possible effect; NLX: Naloxone; NMDA: N- methyl-D-aspartate; NOS: Nitric oxide synthase; OECD: Organization for Economic Cooperation and Development; p.o.: Per oral; PGs: Prostaglandins; QE: Quercetin equivalents; r.p.m.: Rotation per minute; $R_{f}$ : Retention factor; ROS: Reactive oxygen species; SEM: Standard error of mean; SGC: Soluble guanylyl cyclase; TLC: Thin layer chromatography; TNF-a: Tumor necrosis factor-alpha; TPC: Total phenolic content}

\section{Acknowledgements}

Authors are thankful to Professor Dr. Bidyut Kanti Datta, Chairman, Department of Pharmacy, Stamford University Bangladesh for giving permission to carry out the study using facilities of Pharmacology Laboratory.

\section{Funding}

No funding was received for this study.

\section{Availability of data and materials}

The datasets for supporting the outcomes of the study are included in the article.

\section{Authors' contributions}

The study was conceived and designed by MSS and TA. SI collected the plant, did the extraction, and conducted the experiments. MSS performed statistical analysis, interpreted data and drafted the manuscript which was evaluated by all authors. All authors read and approved the final manuscript.

\section{Competing interest}

The authors declare that they have no competing interests.

\section{Ethics approval}

The experiments were conducted under the approval of Ethics Committee of Stamford University Bangladesh (SUB/IAEC/14.07). The Swiss Academy of Medical Sciences and the Swiss Academy of Sciences formulated Ethical Principles and Guidelines for Scientific Experiments on Animals (1995) was followed for in vivo study. Animals were euthanized following AVMA guidelines for the Euthanasia of Animals: 2013 Edition.

Received: 31 January 2016 Accepted: 11 October 2016

Published online: 22 October 2016

\section{References}

1. Navarra T. The encyclopedia of vitamins, minerals, and supplements. New York: Facts on File, Inc.; 2004

2. Li TS. Taiwanese native medicinal plants: phytopharmacology and therapeutic values. London: Taylor and Francis; 2006.

3. Rahman AM, Gulshana MIA. Taxonomy and medicinal uses on amaranthaceae family of Rajshahi, Bangladesh. App Ecol Environ Sci. 2014;2: 54-9.

4. Song MJ, Kim H, Lee BY, Brian H. Analysis of traditional knowledge of medicinal plants from residents in Gayasan National Park (Korea). J Ethnobiol Ethnomed. 2014;10:1-47.

5. Anderson EF. Ethnobotany of hill tribes of northern Thailand. I. medicinal plants of Akha. Econ Bot. 1986;40:38-53.

6. Foster $\mathrm{S}$, Chongxi Y. Herbal emissaries: bringing Chinese herbs to the West: a guide to gardening, herbal wisdom and well-being. Vermont: Healing Arts Press; 1992.

7. Motaleb MA, Abdullah-Al-Mamun MM, Hossain MK, Alam MK, Sultana M. Herbal healing: an old practice for healthy living among Khumi, Marma and Tripura communities of Thanchi upazila, Bangladesh. European J Med Plants. 2015;5:23-52.

8. Yusuf M, Wahab MA, Yousuf MD, Chowdhury JU, Begum J. Some tribal medicinal plants of Chittagong hill tracts, Bangladesh. Bangladesh J Plant Taxonomy. 2007;14:117-28.

9. Kichu M, Malewska T, Akter K, Imchen I, Harrington D, Kohen J, et al. An ethnobotanical study of medicinal plants of Chungtia village, Nagaland, India. J Ethnopharmacol. 2015;166:5-17.

10. Halim MA, Chowdhury MSH, Wadud Al, Uddin MS, Sarker SK, Uddin MB. The use of plants in traditional health care practice of the "Shaiji" community in southwestern Bangladesh. J Trop For Sci. 2007;19:168-75.

11. Afroz SS, Sen US, Islam MJ, Morshed MT, Bhuiyan MSA, Ahmed I, et al. Ethnomedicinal plants of various tribal and folk medicinal practitioners of six localities of Rangamati and Khagrachari districts in Bangladesh. AmEurasian J Sustain Agric. 2013;7:262-71.

12. Asolkar LV, Kakkar KK, Chakre OJ. Second supplement to glossary of Indian medicinal plants with active principles. New Delhi: CSIR; 1992.

13. Wen Y, Islam MT, Tahara S. Phenolic constituents of Celosia cristata L. susceptible to spinach root rot pathogen Aphanomyces cochlioides. Biosci Biotechnol Biochem. 2006;70:2567-70.

14. Xiang C, Meili G, Hui S, Ya DC. Study on chemical constituents of Celosia cristata seed. J Jilin Agric Univ. 2010;32:657-60.

15. Wang Y, Lou Z, Wu QB, Guo ML. A novel hepatoprotective saponin from Celosia cristata L. Fitoterapia. 2010;81:1246-52.

16. Sun ZL, Gao GL, Xia YF, Feng J, Qiao ZY. A new hepoprotective saponin from Semen Celosia cristatae. Fitoterapia. 2011;82:591-4.

17. Balasubrahmanyam A, Baranwal VK, Lodha ML, Varma A, Kapoor HC. Purification and properties of growth stage-dependent antiviral proteins from the leaves of Celosia cristata. Plant Sci. 2000;154:13-21.

18. Warhade MI, Badere RS. Isolation of callus lines of Celosia cristata L. with variation in betalain content. Indian Botanical Soc. 2015;94:89-96.

19. Khan MI. Plant betalains: safety, antioxidant activity, clinical efficacy, and bioavailability. Compr Rev Food Sci Food Saf. 2015. doi:10.1111/1541-4337. 12185.

20. Huskisson EC, Donnelly S. Hyaluronic acid in the treatment of osteoarthritis of the knee. Rheumatology. 1999;38:602-7.

21. Chen WJ, Abatangelo G. Functions of hyaluronan in wound repair. Wound Repair Regen. 1999;7:79-89.

22. Dipankar C, Murugan S, Devi PU. Review on medicinal and pharmacological properties of Iresine herbstii, Chrozophora rottleri and Ecbolium linneanum. Afr J Tradit Complement Altern Med. 2011;8:124-9. 
23. Pyo YH, Yoon MY, Son JH, Choe TB. The effect of Celosia cristata L. ethanol extract on anti-oxidant \& anti-aging activity. Biotechnol Bioprocess Eng. 2008;23:431-8

24. Fitoussi R, Estève D, Delassus AS, Vié K. Impact of Celosia cristata extract on adipogenesis of native human CD34+/CD31-cells. J Cosmet Dermatol SciAppl. 2013:3:55-63.

25. Saqib F, Janbaz KH, Sherwani MK. In vitro inhibitory potential of methanolic extract of Celosia argentea var. cristata on tyrosinase, acetylcholinesterase and butyrylcholinesterase enzymes. Bangladesh J Pharmacol. 2015;10:449-54.

26. Rubini $D$, Sudhahar $D$, Anandaragopal K. Phytochemical investigation and anthelmintic activity of Celosia cristata leaf extract. Int Res J Pharm. 2012;3: $335-6$.

27. Iweala EEJ, Ogidigo JO. Effect of Celosia argentea F. Cristata Schinz. on prostate specific antigen, antioxidant status and hematological parameters in rats induced with benign prostate hyperplasia. Asian J Biochem. 2015;10: $42-51$.

28. Pyo YH, Yoon MY, Han YS. Anti-inflammatory activity of Celosia cristata L. J Korean Soc Esthetics Cosmeceutics. 2011;6:165-72.

29. Malomo SO, Ore A, Yakubu MT. In vitro and in vivo antioxidant activities of the aqueous extract of Celosia argentea leaves. Indian J Pharmacol. 2011:43:278-85

30. Ghani A. Practical Phytochemistry. Dhaka: Parash Publishers; 2005.

31. Gavillán-Suárez J, Aguilar-Perez A, Rivera-Ortiz N, Rodríguez-Tirado K, Figueroa-Cuilan W, Morales-Santiago L, et al. Chemical profile and in vivo hypoglycemic effects of Syzygium jambos, Costus speciosus and Tapeinochilos ananassae plant extracts used as diabetes adjuvants in Puerto Rico. BMC Complement Altern Med. 2015;15:244.

32. Singelton VR, Orthifer R, Lamuela-Raventos RM. Analysis of total phenols and other oxidation substrates and antioxidants by means of FolinCiocalteu reagent. Methods Enzymol. 1999;299:152-78.

33. Selim SA, Adam ME, Hassan SM, Albalawi AR. hemical composition, antimicrobial and antibiofilm activity of the essential oil and methanol extract of the Mediterranean cypress (Cupressus sempervirens L.). BMC Complement Altern Med. 2014;14:179.

34. Wang SS, Wang DM, Pu WJ, Li DW. Phytochemical profiles, antioxidant and antimicrobial activities of three Potentilla species. BMC Complement Altern Med. 2013;13:321.

35. Talwar S, Jagani HV, Nayak PG, Kumar N, Kishore A, Bansal P, et al. Toxicological evaluation of Terminalia paniculata bark extract and its protective effect against $\mathrm{CCl}_{4}$-induced liver injury in rodents. BMC Complement Altern Med. 2013;13:127.

36. Chowdhury A, Rahman M, Chowdhury MR, Uddin J, Sayeed MA, Hossain A. Antinociceptive and cytotoxic activities of an epiphytic medicinal orchid: Vanda tessellata Roxb. BMC Complement Altern Med. 2014;14:464.

37. Eddy NB, Leimbach D. Synthetic analgesics: II. Dithienylbutinyl and Dithienylbutylamines. J Pharmacol Exp Ther. 1953;107:385-93.

38. D'Amour FE, Smith DL. A method for determining loss of pain sensation. J Pharmacol Exp Ther. 1941;72:74-9.

39. Khatun A, Imam MZ, Rana MS. Antinociceptive effect of methanol extract of leaves of Persicaria hydropiper in mice. BMC Complement Altern Med. 2015; 15:63.

40. de Sá PG, Nunes XP, de Lima JT, Fontana AP, de Siqueira Filho JA, QuintansJúnior $\mathrm{L}$, et al. Antinociceptive effect of ethanolic extract of Selaginella convoluta in mice. BMC Complement Altern Med. 2012;12:187.

41. Rodrigues MR, Kanazawa LK, das Neves TL, da Silva CF, Horst H, Pizzolatti MG, et al. Antinociceptive and anti-inflammatory potential of extract and isolated compounds from the leaves of Salvia officinalis in mice. J Ethnopharmacol. 2012;139:519-26.

42. Khan H, Saeed M, Gilani AUH, Khan MA, Khan I, Ashraf N. Antinociceptive activity of aerial parts of Polygonatum verticillatum: attenuation of both peripheral and central pain mediators. Phytother Res. 2011;25:1024-30.

43. Abacioglu N, Tunctan B, Akbulut E, Cakici I. Participation of the components of I-arginine/nitric oxide/cGMP cascade by chemically-induced abdominal constriction in the mouse. Life Sci. 2000;67:1127-37.

44. Perimal EK, Akhtar MN, Mohamad AS, Khalid MH, Ming OH, Khalid S, et al. Zerumbone-induced antinociception: involvement of the l-argininenitric oxide-cGMP-PKC-K+ ATP channel pathways. Basic Clin Pharmacol Toxicol. 2011;108:155-62

45. Mohamad AS, Akhtar MN, Khalivulla SI, Perimal EK, Khalid MH, Ong HM, et al. Possible participation of nitric oxide/cyclic guanosine monophosphate/protein kinase C/ATP-sensitive $\mathrm{K}^{+}{ }^{+}$) channels pathway in the systemic antinociception of Flavokawin B. Basic Clin Pharmacol Toxicol. 2011;108:400-5.

46. Srinivasan K, Muruganandan S, Lal J, Chandra S, Tandan SK, Raviprakash V, et al. Antinociceptive and antipyretic activities of Pongamia pinnata leaves. Phytother Res. 2003;17:259-64.

47. Chapman CR, Casey KL, Dubner R, Foley KM, Gracely RH, Reading AE. Pain measurement: an overview. Pain. 1985;22:1-31.

48. Jinsmaa Y, Fujita Y, Shiotani K, Miyazaki A, Li T, Tsuda Y, et al. Differentiation of opioid receptor preference by [Dmt1] endomorphin-2-mediated antinociception in the mouse. Eur J Pharmacol. 2005;509:37-42.

49. Jinsmaa Y, Okada Y, Tsuda Y, Shiotani K, Sasaki Y, Ambo A, et al. Novel 2', 6'dimethyl-I-tyrosine-containing pyrazinone opioid mimetic $\mu$-agonists with potent antinociceptive activity in mice. J Pharmacol Exp Ther. 2004;309:432-8.

50. De Souza MM, Pereira MA, Ardenghi JV, Mora TC, Bresciani LF, Yunes RA, et al. Filicene obtained from Adiantum cuneatum interacts with the cholinergic, dopaminergic, glutamatergic, GABAergic, and tachykinergic systems to exert antinociceptive effect in mice. Pharmacol Biochem Behav. 2009;93:40-6.

51. Ikeda Y, Ueno A, Naraba H, Oh-ishi S. Involvement of vanilloid receptor VR1 and prostanoids in the acid-induced writhing responses of mice. Life Sci. 2001:69:2911-9.

52. Bley KR, Hunter JC, Eglen RM, Smith JA. The role of IP prostanoid receptors in inflammatory pain. Trends Pharmacol Sci. 1998:19:141-7.

53. Le Bars D, Gozariu M, Cadden SW. Animal models of nociception. Pharmacol Rev. 2001;53:597-652.

54. Parada CA, Tambeli CH, Cunha FQ, Ferreira SH. The major role of peripheral release of histamine and 5-hydroxytryptamine in formalin-induced nociception. Neuroscience. 2001;102:937-44.

55. Dalal A, Tata M, Allegre G, Gekiere F, Bons N, Albe-Fessard D. Spontaneous activity of rat dorsal horn cells in spinal segments of sciatic projection following transection of sciatic nerve or of corresponding dorsal roots. Neuroscience. 1999:94:217-28.

56. Hunskaar S, Hole K. The formalin test in mice: dissociation between inflammatory and non-inflammatory pain. Pain. 1987;30:103-14.

57. Tjølsen A, Berge OG, Hunskaar S, Rosland JH, Hole K. The formalin test: an evaluation of the method. Pain. 1992;51:5-17.

58. Trongsakul S, Panthong A, Kanjanapothi D, Taesotikul T. The analgesic, antipyretic and anti-inflammatory activity of Diospyros variegata Kruz. J Ethnopharmacol. 2003;85:221-5.

59. Beauparlant P, Hiscott J. Biological and biochemical inhibitors of the NF-KB/ Rel proteins and cytokine synthesis. Cytokine Growth Factor Rev. 1996;7: $175-90$.

60. Beirith A, Santos AR, Calixto JB. Mechanisms underlying the nociception and paw oedema caused by injection of glutamate into the mouse paw. Brain Res. 2002;924:219-28.

61. Ribas CM, Meotti FC, Nascimento FP, Jacques AV, Dafre AL, Rodrigues ALS, et al. Antinociceptive effect of the Polygala sabulosa hydroalcoholic extract in mice: evidence for the involvement of glutamatergic receptors and cytokine pathways. Basic Clin Pharmacol Toxicol. 2008;103:43-7.

62. Presti D, Scott JE. Hyaluronan-mediated protective effect against cell damage caused by enzymatically produced hydroxyl $(\mathrm{OH} \cdot)$ radicals is dependent on hyaluronan molecular mass. Cell Biochem Funct. 1994;12:281-8.

63. Fukuda K, Takayama M, Ueno M, Oh M, Asada S, Kumano F, et al. Hyaluronic acid inhibits interleukin-1-induced superoxide anion in bovine chondrocytes. Inflamm Res. 1997:46:114-7.

64. Peng H, Zhou JL, Liu SQ, Hu QJ, Ming JH, Qiu B. Hyaluronic acid inhibits nitric oxide-induced apoptosis and dedifferentiation of articular chondrocytes in vitro. Inflamm Res. 2010;59:519-30.

65. Neuman MG, Nanau RM, Oruña-Sanchez L, Coto G. Hyaluronic Acid and wound healing. J Pharm Pharm Sci. 2015;18:53-60.

66. Alves DP, Duarte ID. Involvement of ATP-sensitive K+ channels in the peripheral antinociceptive effect induced by dipyrone. Eur J Pharmacol. 2002:444:47-52.

67. Jesse CR, Savegnago L, Nogueira CW. Role of nitric oxide/cyclic GMP/K $\mathrm{K}^{+}$ channel pathways in the antinociceptive effect caused by 2, 3-bis (mesitylseleno) propanol. Life Sci. 2007:81:1694-702.

68. Lawson K. Potassium channel activation: a potential therapeutic approach? Pharmacol Ther. 1996;70:39-63.

69. Bodhinathan K, Kumar A, Foster TC. Intracellular redox state alters NMDA receptor response during aging through $\mathrm{Ca} 2+$ /calmodulin- dependent protein kinase II. J Neurosci. 2010;30:1914-24. 
70. Kempuraj D, Madhappan B, Christodoulou S, Boucher W, Cao J, Papadopoulou $\mathrm{N}$, et al. Flavonols inhibit proinflammatory mediator release, intracellular calcium ion levels and protein kinase $C$ theta phosphorylation in human mast cells. Br J Pharmacol. 2005;145:934-44.

71. Starec M, Waitzova D, Elis J. Evaluation of the analgesic effect of RG-tannin using the" hot plate" and" tail flick" method in mice. Cesk Farm. 1988;37: 319-21

72. Ramesh M, Rao YN, Rao AA, Prabhakar MC, Rao CS, Muralidhar N, et al. Antinociceptive and anti-inflammatory activity of a flavonoid isolated from Caralluma attenuata. J Ethnopharmacol. 1998;62:63-6.

73. Morteza-Semnani K, Mahmoudi M, Heidar MR. Analgesic activity of the methanolic extract and total alkaloids of Glaucium paucilobum. Methods Find Exp Clin Pharmacol. 2006;28:151-5.

Submit your next manuscript to BioMed Central and we will help you at every step:

- We accept pre-submission inquiries

- Our selector tool helps you to find the most relevant journal

- We provide round the clock customer support

- Convenient online submission

- Thorough peer review

- Inclusion in PubMed and all major indexing services

- Maximum visibility for your research

Submit your manuscript at www.biomedcentral.com/submit
Biomed Central 